\title{
Full Sister
}

National Cancer Institute

\section{Source}

National Cancer Institute. Full Sister. NCI Thesaurus. Code C111202.

A female who shares with her sibling the genetic makeup inherited from both of the biological parents. 